\title{
Erratum to: Selective measures in data envelopment analysis
}

\author{
Mehdi Toloo $^{1}$ • Mona Barat ${ }^{2}$ - Atefeh Masoumzadeh
}

\section{Erratum to: Ann Oper Res (2015) 226:623-642 DOI 10.1007/s10479-014-1714-3}

The last $m+s$ constraints in models $(8,12$ and 13) are extra and must be removed.

In the first two paragraphs in Section 4, reference should be read as Lee and Zhu [23].

The online version of the original article can be found under doi:10.1007/s10479-014-1714-3.

$凶 \quad$ Mehdi Toloo

mehdi.toloo@vsb.cz; m_toloo@yahoo.com

1 Department of Business of Administration, Technical University of Ostrava, Sokolská třída 33, 70121 Ostrava 1, Czech Republic

2 Department of Mathematics, Mahshahr Branch, Islamic Azad University, Mahshahr, Iran

3 Department of Mathematics, Islamic Azad University, Central Tehran Branch, Tehran, Iran 